\title{
Higher Education Fund Raising: What is the President to Do?
}

Received (in revised form): February 24, 2005

\section{Robin Satterwhite}

C. Robin Satterwhite, MBA, Ed.D. is an Assistant Professor and Associate Dean for Education Outcomes and Technologies for the Texas Tech University Health Sciences Center School of Allied Health Sciences.

\section{Brent Cedja}

Brent D. Cejda, Ph.D. is an Associate Professor of Higher Education at Texas Tech University. He teaches in the areas of higher education finance and institutional advancement.

\begin{abstract}
Reductions in state and federal allocations to higher education are requiring colleges and universities to seek alternative sources of funding, and higher education institutions are becoming progressively more involved in fund raising. This increased dependence on private sources of funding emphasizes the need for more in-depth studies of higher education fund raising, particularly for additional information regarding the function of the president in the fund-raising process. The primary purpose of this study is to examine the function of presidents in the fund-raising process within higher education. The study focuses on the president and the chief development officer in public four-year institutions within the state of Texas with capital campaigns less than $\$ 100 \mathrm{~m}$.
\end{abstract}

Author's Contact Address:

C. Robin Satterwhite

3601 4th Street, STOP 6225

Lubbock, TX 79430, USA

Phone: +1806 7432262

Email: robin.satterwhite@ttuhsc.edu
The study uses a multiple case design, allowing the researcher to examine subjects in a real-life setting and, consequently, to identify specific themes relating to a phenomenon. The themes that emerged in the analysis of data related to six specific presidential behaviors within the broad context of fund raising: (1) strategic planning, (2) coordinating external stakeholders, (3) building teams, (4) coordinating internal stakeholders, (5) directing the fund-raising process, and (6) allocating resources to achieve fund-raising goals.

Keywords:

fund raising, institutional advancement, president, CEO, finance

\section{Introduction}

Costs associated with the delivery of higher education have escalated over the years; however, the sources of funding have become increasingly limited and even stagnant in many situations. ${ }^{1}$ Funding uncertainties have not just recently developed. Rather, they have existed within higher education for many years and have continued to grow, 
reaching critical levels. Consequently, universities are focusing on alternative sources of funding to meet the operational needs of the institution. Specifically, fund raising is expected to provide an increasing percentage of the operating and capital revenues of higher education institutions. ${ }^{2}$

Within the broader context of fund raising, there has been an increased dependence upon campaigns to support the mission of higher education institutions. ${ }^{3}$ Most often, fund raising in higher education is associated with universities with multibillion dollar endowments, or with private institutions that have historically relied more heavily on fund raising than have their public counterparts. More recently, however, universities with smaller capital campaigns are equally interested in raising dollars to meet their educational mission. The vast majority of higher education institutions, from research universities to community colleges, are now committing substantial resources to fund raising. Not surprisingly, college and university presidents have become highly involved in the fund-raising process and remain a key component in the success of campaigns. ${ }^{4}$

\section{Problems}

Three distinct problems highlight the need for institutions of higher education to emphasize fund raising. First, state funding for higher education is decreasing significantly. Secondly, university's reliance on increased tuition to offset increased operational costs combined with decreased governmental support has become problematic to the long-term ability to maintain educational affordability. Last, operational costs continue to rise at alarming rates for higher education institutions. Fund raising has become a necessity in public institutions to support operations and to maintain competitive tuition rates. ${ }^{5}$ Clearly, this issue expands across all levels of higher education. However, public master's and doctoral institutions will be highlighted in the focus of this study.

The last three decades have marked consistent decreases in state funding. Specifically, the 2002-03 academic year showed more dramatic state cuts than any other year in the last decade, posting increases of only 1.2 percent in current dollars. ${ }^{6}$ Moreover, growth in state appropriations for fiscal year 2003 has dropped to near zero, without consideration of inflation. Most recently, a survey conducted by the Center for the Study of Education Policy at Illinois State University showed that states' budgets for fiscal year 2003-04 showed larger cuts to public higher education than any other year during the 45-year history of the survey. This cut equaled 2.1 percent across the 50 states, with some states acknowledging that more cuts had been implemented since the publication of the survey. $^{7}$

Future projections for state support for higher education are extremely bleak. Hovey has explored fiscal support for higher education among all the states. $\mathrm{He}$ concludes that given the poor economic performance of the states as well as the decreased ability for institutions of higher education to compete with other programs for state dollars, there will be significant funding shortfalls for public institutions for the eight years following his study. His assessment reflects an economic projection that more closely parallels "normal" growth. However, he notes that if economic growth is lower than "normal" there would be even more dire results. ${ }^{8}$

Institutions have responded to the decreasing sources of state funding by 
reverting to other sources of revenue. The National Association of State Universities and Land-Grant Colleges identified a 10 percent average increase in tuition rates across the nation between the 2003 and 2004 academic years. ${ }^{9}$ Wellman identified a near fivefold increase in tuition rates over the last two decades. ${ }^{10}$ Another report shows that tuition increases exceeded the consumer price index increases by 5 percent in the years 1981 through 1993 and that, between 1983 and 1992, costs of attending college increased by 22.8 percent, while median family incomes only increased 6.4 percent. ${ }^{11}$ These increases have not gone unnoticed. Increasing pressures from a discontented public, Congress, and even some state legislators have emphasized the immediate need to limit tuition increases. ${ }^{12}$

In addition to decreases in revenue sources, higher education institutions have seen a marked increase in operating costs. From 1980 to 1996 public postsecondary institutions increased expenditures nearly $\$ 126 \mathrm{bn}$. In constant dollars, the increase for the same period amounts to over $\$ 60 \mathrm{bn}$. These increases equal approximately 300 percent and 47 percent, respectively, over the 16 -year period. ${ }^{13}$ In the public university setting, the educational and general expenditures per student were $\$ 19,700$ annually in 1996 , an increase from $\$ 15,391$ in $1980 .{ }^{14}$ Increased operating costs have, in large part, been passed on to students in the form of nearly 190 percent rise in tuition from fiscal year 1984-1985 to fiscal year 1999$2000 .^{15}$

It is evident that there is a very clear dilemma in the funding of higher education in America. Government resources are waning, costs associated with the delivery of education are increasing at a disproportionate rate to inflation, and tuition is increasing at alarming rates.
Institutions must work diligently to shift their reliance from state and federal funds and focus their energies on improving fund raising.

The president or CEO of the college/ university is identified as one of the most significant positions within the university structure for seeking external funds for the institution. Therefore, with an everincreasing need for external funding, the president must prepare quickly and appropriately to play an integral role in acquiring such funds. While some presidents have had development or fundraising experience in other capacities, many must rely on their intuitive expertise or others' experiences to establish successful fund-raising campaigns. This study will examine the different behaviors and success factors identified for the office of the president or CEO of the university. Additionally, it will focus on the individual characteristics that prove to be the most successful among those presidents surveyed.

\section{Literature Review}

Throughout history, the president of the institution has continually been highly involved in the process of raising funds for the institution. ${ }^{16}$ This position continues to have the greatest impact on the success of any higher education fundraising campaign. Presidents play a very positive role in representing the university and cultivating successful relationships with potential donors. Furthermore, the president should regularly be a key player in actually making the request for funds from larger donors. ${ }^{17}$ Presidents typically spend 60 percent of their time meeting with outsiders and constituents. This indicates that the president's influence upon the university primarily revolves around external contributions, including legislative activity and capital campaigns. 
The president should bring focus to any fund-raising effort. Moreover, "as the essence of the institution, the president inspires donor confidence and creates the climate in which fund raising takes place." 18

The position of the president must perform several very critical activities to supplement the efforts of fund-raising staff, administrators, trustees, and volunteers. Clearly, the president, as the head of the university, should provide the overall guidance for the university and its campaigns. ${ }^{19}$ This would seem very obvious for any presidential figure, but without this vital direction and guidance, the university cannot effectively maintain a fund-raising campaign. More importantly, if the president is not fulfilling this role, the university more than likely has some other very significant problems that it should address. Kerr notes that attracting financial resources, allocating the resources, and formulating the vision for the university are among the most significant roles of the college president. $^{20}$ The president must also identify within the university the most significant financing needs for which private funds should be sought. ${ }^{21}$ This process should be closely aligned with the planning of the university. The plan, however, should not exceed the realistic expectations of what can be funded through institutional advancement. The president should temper his or her ideas and goals to match the overall potential of the university and the available resources. ${ }^{22}$

Cook concludes that there are two constants in higher education. First, he states that there always has been and there always will be a need for strong leadership in higher education institutions. Second, there will always be a near insatiable need for resources in higher education. ${ }^{23}$ It is imperative that presidents are able to assess these needs within an institution and effectively apply their time, talents, and energy to accomplish these two invariable needs of the institution. In a study of the presidential role in fundraising campaigns greater than $\$ 100 \mathrm{~m}$, Cook and Lasher determine that the president is undoubtedly the central player in the fund-raising process in higher education. Secondly, they emphasize that the fund-raising effort must be addressed from a team approach and simply cannot be achieved by any single individual. Thirdly, while technical aspects of fund raising can be transferred from institution to institution, fund raising is situation-specific and must be designed specifically in consideration of the four influences noted previously in light of the social exchange process. Last, fund raising should be measured by its effectiveness and success. ${ }^{24}$ Fund-raising success clearly is easier to measure in that it is defined by the accomplishment of specific goals. Effectiveness, however, is based on the long-term stability and maturity of the institution's fund-raising efforts. The effectiveness has a fundamental impact on the overall operations of the institution.

\section{Methodology}

This study sought to examine the functions of the president/CEO of a university with a capital campaign less than $\$ 100 \mathrm{~m}$. Through a detailed analysis, the goal was to identify specific themes and patterns that contribute to the understanding of fund raising and, more specifically, highlight the contribution that the president makes in the fundraising process. The specific qualitative design used in this study is the multiple case study. Within the different cases, the president/CEO of three different universities who were involved with or 
had completed capital campaigns of less than $\$ 100 \mathrm{~m}$ were interviewed.

Additionally, the chief development officers within these universities were interviewed. Finally, to provide appropriate triangulation, archival data was studied to ensure consistency of the information gained regarding the role and function of the president in the fundraising process. This examination of the detailed information facilitated the emergence of themes and patterns in response to the data collection and analysis of the data. ${ }^{25}$ Gall et al. explain that one of the primary focuses of case study research is to identify themes that explain the phenomenon being studied. ${ }^{26}$ The variables focused upon in this study are primarily the president, and secondarily, fund-raising processes and the chief development officer.

Three institutions were identified as subjects for this study. The average enrollment at these universities is approximately $9,000 .{ }^{27}$ As defined by the Carnegie Foundation, one of the universities is Master's University I and two of the universities are Doctoral/ Research Universities-Intensive. ${ }^{28}$ Historically, none of the institutions has a record of raising substantial gifts. While each has gone through some type of capital campaign in the past, the universities' increased reliance on private funding emphasizes the need to improve fund-raising efforts.

\section{Themes}

A number of themes emerging from the data analysis describe how the president "effectively" functions in the fund-raising process. Three primary and three secondary behaviors surfaced as the most prominent functions of the presidency in this regard. The primary behaviors include: (1) strategic planning and developing a vision for the university, (2) coordinating and interacting with key external stakeholders, and (3) building effective operational teams. The secondary behaviors include: (1) coordinating and interacting with key internal stakeholders, (2) directing the fund-raising process, and (3) allocating appropriate resources to enable fund-raising success. These themes represent issues that were consistently identified and/or emphasized by the presidents as well as the chief development officers through the interview sessions. The themes are also recurrent within archival data. Moreover, the themes were consistently reported by both the presidents and the chief development officers, with very little variance in the perception of the roles that the president plays in the fundraising process.

Figure 1 outlines the specific occurrences of each of these themes throughout the interview process.

\section{Strategic planner/visionary}

Fund raising relies very heavily on the strategic plan and vision of the university, and the president must be the primary individual in establishing this plan and vision. There are a number of reasons for this function. Most important, it is essential that all operations within the

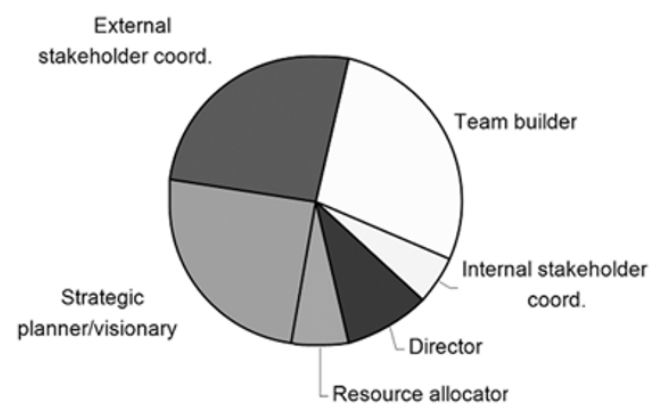

Figure 1: Presidential behaviours 
university stem from the institutional mission and the associated strategic plan.

While funding mechanisms must be considered in the strategic planning process, the goals of the fund-raising process must be consistent with the goals of the strategic plan and the institutional vision. All activities of the fund-raising process must reflect the needs of the institution and the objectives outlined in the strategic plan. The establishment of the strategic plan and vision, therefore, is monumentally important in the overall development of the institutional advancement plan and daily operations. Because of the extensive impact of the strategic plan and vision on the fundraising efforts, the president's role in the planning process and his or her vision remain critical components of the position.

\section{Coordinator for external stakeholders}

There are a number of ways in which presidents work with external stakeholders to achieve the fund-raising goals of the university. They must be highly attuned to influential sources that may provide direction, contacts, or personal gifts toward the effort. Each university president must carefully scan and analyze the external horizon to determine which stakeholders are most significant in accomplishing the established goals. He or she, through coordination with key team members, must then carefully cultivate each of these stakeholders to maximize the fund-raising benefit to the institution.

Alumni remain one of the most influential groups among all external stakeholders to the university.

Accordingly, the president must place a special emphasis on organizing, focusing, and challenging this group to represent and fulfill the needs of the university.
Within universities that are implementing smaller capital campaigns, the development of the alumni is absolutely imperative. The university must first organize this group to ascertain the potential for giving and support. With often poorly developed alumni databases, this task can be very timeconsuming and quite challenging. Nonetheless, if the university is unable to identify the appropriate level of alumni participation and support, it will be difficult to launch a comprehensive capital campaign.

Political groups and figureheads are also key external stakeholders to the university. The president must maintain constant communication with groups who influence the institution from a number of different capacities, including legislative actions such as establishing funding levels for ongoing operations. Presidents identified that a significant amount of their time in relation to fund raising involved dealing with key state and local political groups.

Presidents must also work very carefully with institutional foundations that are often integral in the fund-raising efforts of the university. The president must purposefully organize this group's efforts and carefully navigate university relations with this organization. Foundations can be structured in a number of different ways, often unique to their respective university setting. However, they are instrumental in the planning, implementation, and overall success of the capital campaign. It is the president's responsibility to match the goals of the foundation with those of the university, not unlike those of influential alumni groups. The president must then carefully foster the relationships with the foundation in order to promote the most appropriate fund-raising leaders and 
establish the most reasonable fund-raising goals.

Individual and corporate donors, independent of alumni or foundation groups, are also important constituencies in fund-raising efforts. One of the fundamental success factors identified by the presidents and development officers alike is establishing long-term relationships and giving patterns with key donors. The president is highly instrumental in this process. A personal relationship between the president and key donors can be the basis upon which to build future fund-raising networks. The attention from the president as well as the reciprocal influence that the donor makes on the president is essential to solidify many fund-raising efforts as well as develop opportunities for future giving relationships. It is clear that the development team is typically very active in cultivating these relationships and formulating the ultimate contribution, but the president must have a tactical influence throughout the development process.

\section{Team builder}

The president/CEO simply cannot accomplish all of the tasks unilaterally. Therefore, building teams, both within the institution as well as external to the institution, becomes a major component in the successful implementation of a campaign. Simply put, while the president is an integral player in the fund-raising process, other key individuals and teams provide an even more significant function in the overall success of the fund-raising effort. Consequently, the team that the president builds in preparation for the fund-raising process is a substantial component in the overall success of the campaign.

The development of a valuable fundraising team is often centered on identifying a talented chief development officer (CDO). Presidents identify this position as monumental in the institutional advancement process. In addition to securing a proficient CDO and developing an institutional advancement team, the president must also establish numerous other teams in order to achieve the institutional goals in fund raising. The president must involve key academic and staff leaders throughout the institution to play significant roles. Academic deans, key faculty members, vice-presidents, and other staff members must all work on functional teams to meet fund-raising and operational goals.

The ability of the president to work well with these teams is not only essential to the accomplishment of the fund-raising objectives, it is crucial in aiding the president in meeting the other multiple tasks on the periphery of the fund-raising effort. Clearly, the president is not always the leader of every team; therefore, it is imperative that he or she can easily interface with the multiple teams and understand the role to be played within those teams.

In addition to building functional internal teams, the president must carefully develop purposeful teams outside the institution. These teams are helpful in identifying potential donors, guiding the president and his or her cabinet through fund-raising efforts, and in holding the institution accountable for achieving goals. As noted before, alumni groups, regents, and other key external stakeholders are well represented in these external teams. The ability, then, of the president to assemble these teams, work collaboratively with them, and energize them to succeed is a necessary function of the president throughout the fund-raising effort. 


\section{Coordinator for internal stakeholders}

The team-building process also dictates that the president works closely with key internal stakeholders including faculty, staff, vice-presidents, deans, and other key personnel. The process extends beyond the mere development and utilization of instrumental teams. The president must also perform an internal SWOT (strengths, weaknesses, opportunities, threats) analysis in preparation for any strategic fund-raising effort. Presidents and CDOs alike identify the need for tactical preparation techniques prior to the implementation of a fund-raising effort. Such an analysis involves identifying those internal stakeholders who will be supportive or nonsupportive and determining how these individuals can be utilized in the institutional fund-raising efforts. All individuals and groups must be educated and managed by the president in order to successfully realize fundraising goals.

The president must on occasion overcome other institutional barriers. These may include organizational structures, historical resistance, or limited experience among internal players. The preparatory phases of fund raising are prerequisites to build the framework for a fund-raising thrust; without them, institutional advancement infrastructure will be built with little foundational support. This is particularly evident in institutions that have little fund-raising history. The mechanisms and momentum needed to implement the process are often underdeveloped or are completely absent. The president, therefore, must work carefully to guide the institution through a very important phase of preparing for a campaign through education, reorganization, and strategic planning.

\section{Resource allocator}

There are a number of different tasks and operations that must be implemented to develop a successful fund-raising campaign. These cannot be accomplished without a sufficient level of human and financial resources. The right number of qualified individuals must be employed to perform all of the necessary functions of the campaign. Additionally, and just as important, the president must dedicate the financial resources required to implement the most effective fund-raising strategies. These needs could range from hiring consultants to developing and purchasing fund-raising supplies. The president, therefore, must carefully monitor the operations to ensure consistency with pre-established missions, goals, and specific timeframes. If valuable resources are not efficiently utilized, the integrity of the campaign rapidly digresses and may fail to parallel or support the overall university mission.

\section{Director}

Once the institution has been prepared for the fund-raising process, infrastructure has been developed, and personnel are organized, the president must essentially direct the institution towards the desired goals of the campaign. The president has a distinct vantage point, enabling him or her to see all of the different players and environments with which the institution is dealing. As a result, the president has the responsibility of providing sage guidance and direction for all of the different teams and players in consideration of the overall fund-raising situation.

The president, therefore, must be everpresent and attentive to the fund-raising process lest potential problems or opportunities for success are not addressed effectively. This is not to imply 
that the teams are not exceptionally talented within their own situations; rather, the president has the advantage of the institutional vision, team operations across a very broad playing field, and the influence from key internal and external stakeholders that may provide key strategies for implementing a successful campaign.

\section{Conclusion}

The cases studied each provided a different perspective on the processes and stages of fund raising. However, each respective case had very similar issues that they addressed, including limited fundraising histories and a distinct need for fund raising to meet operational demands. Unquestionably, universities of all sizes struggle with limited funding from state and federal sources; and they are searching for other funding alternatives. As a result, the universities studied within the cases identified the absolute need to raise dollars to continue to meet their educational missions.

In examining the fund-raising processes at these particular universities, distinct and consistent themes emerged regarding the function of the presidents. Strategic planning, team building, and external stakeholder management surfaced as the fundamental and most pressing roles that the president plays in the process.

However, the roles of resource allocator, internal stakeholder coordinator, and director were also emphasized as critical roles upon which the president should focus. These themes were by and large consistent with the literature relating to university presidents and fund raising in general among universities with much larger capital campaigns.

Presidents, therefore, plays a multifaceted role in their operational and academic capacities as well as within their role in the fund-raising process. The fundraising process, while it has many specific and intrinsic components, cannot be separated from the fundamental roles and responsibilities of the president. The president, therefore, must be highly talented in order to meet all of the demands of the complex fund-raising campaign in coordination with those traditional duties of the president. The need for these talents and abilities continues to surface within the position of the president and will only increase in importance as the university environment and funding sources evolve.

\section{References}

1. S. Beaird and W. E. Hayes (1999), Building an Endowment: What, Why, and How, National Catholic Educational Association, Washington, DC; C. Kerr (1980), "New imperatives for private support of higher education," Currents, 6, pp. 8-11.

2. W. B. Cook (1994), "Courting philanthropy: The role of university presidents and chancellors in fund raising," Unpublished doctoral dissertation, University of Texas at Austin.

3. Beaird and Hayes (1999), Building an Endowment, op. cit.; Cook (1994), "Courting philanthropy," op. cit.; A. Hamlin (1990), "The president as salesman," Educational Record, 71, 1, pp. 11-14; J. Harvey, R. M. Williams, R. J. Kirshstein, A. S. O’Malley, and J. V. Wellman (1998), Straight Talk About College Costs and Prices, Report of the National Commission on the Cost of Higher Education, ERIC Document Reproduction Service No. ED 416762; M. Hnetka (1999), "Mastering the art of fundraising," Marketing, 104, p. 23; C. Kerr (1993), Presidents Make a Difference, Association of Governing Boards of Universities and Colleges, Commission on Strengthening Presidential Leadership, Washington, DC.

4. Kerr (1993), Presidents Make a Difference, op. cit.; M. J. Worth (1993), Educational Fund Raising: Principles and Practice, The Oryx Press, Phoenix, AZ.

5. Beaird and Hayes (1999), Building an Endowment, op. cit.; Kerr (1980), "New imperatives for private support of higher education," op. cit.; Cook (1994), "Courting philanthropy," op. cit.; Hamlin (1990), "The president as salesman," op. cit.; Harvey et al. (1998), Straight Talk About College Costs and Prices, op. cit.; Hnetka (1999), "Mastering the art of fundraising," op. cit.

6. W. Trombley (2003), "The rising price of higher education," College affordability in jeopardy, special supplement to National CrossTalk, Winter, pp. 1-12. 
7. M. Arnone (2004), "State spending for colleges drops over all for first time in 11 years," Chronicle of Higher Education, 50, 19, p. A24. Available online at <http://chronicle.com/free/v50/i19/19a02401.htm >.

8. H. A. Hovey (1999), State Spending for Higher Education in the Next Decade: The Battle to Sustain Current Support (Report No. NCR-99-3), The National Center for Public Policy and Higher Education, San Jose, CA, ERIC Document Reproduction Service No. ED 439633.

9. Fall Tuition Rates, Academic 2004-2005 (Oct. 25, 2004), National Association of State Universities and Land-Grant Colleges, Washington, DC.

10. J. Wellman (1999), The Tuition Puzzle: Putting the Pieces Together. The New Millennium Project on Higher Education Costs, Pricing, and Productivity. The Institute for Higher Education Policy, Washington, DC.

11. D. Hossler, J. P. Lund, and J. Ramin, "State funding for higher education: The Sysyphean task," Journal of Higher Education, 68, pp. 160-90.

12. A. Klein (2004), "States move to limit increases in tuition: Colleges say raising fees is the only way they can make up for budget cuts," Chronicle of Higher Education, 50, 26, p. 26A; W. Trombley (2000), "The scary cost of college: Public concerns remain about the escalating expense of higher education. National CrossTalk, 8 (1).

13. US Department of Education (2001), National Center for Education Statistics. Available online at $\langle$ http://nces.ed.gov/programs/digest/d01/lt3.asp〉.

14. D. B. Johnstone (2001), "Higher education and those 'Out of control costs'." Study of College Costs and prices: 1988-1989 to 1997-1998, Vol. 2. US Department of Education, Office of Educational Research and Improvement, NCES Publication No. 2002-158.

15. Ibid.
16. W. B. Cook and W. F. Lasher (1996), "Toward a theory of fund raising in higher education," Review of Higher Education, 20, 1, pp. 33-51.

17. G. L. Essex and C. Ansbach (1993), "Fund raising in a changing economy: Notes for presidents and trustees," Foundation Development Abstracts, III (2).

18. J. L. Fisher (1984), Power of the Presidency, American Council on Education, Macmillan Publishing Company, New York, p. 165.

19. R. H. Weingartner (1996), Fitting Form to Function: A Primer on the Organization of Academic Institutions. The Oryx Press, Phoenix, AZ; Essex and Ansbach (1993), "Fund raising in a changing economy," op. cit.

20. Kerr (1993), Presidents Make a Difference, op. cit.

21. Essex and Ansbach (1993), "Fund raising in a changing economy," op. cit.

22. W. K. Willmer (1993), "Blueprint for a small college: Ten building blocks for strong advancement in challenging times," Currents, 19, 9, pp. 36-40.

23. Cook (1994), "Courting philanthropy," op. cit.

24. Cook and Lasher (1996), "Toward a theory of fund raising in higher education," op. cit.

25. J. W. Creswell (1994), Research Design: Qualitative and Quantitative Approaches, Sage, Thousand Oaks, CA; J. W. Creswell (1998), Qualitative Inquiry and Research Design: Choosing Among Five Traditions, Sage, Thousand Oaks, CA; M. D. Gall, W. R. Borg, and J. P. Gall (1996), Educational Research: An Introduction, 6th edn., Longman, White Plains, NY.

26. Gall et al. (1996), Educational Research, op. cit.

27. Texas Higher Education Coordinating Board (2004). Available online at 〈http://www.thecb.state.tx.us >.

28. The Carnegie Foundation for the Advancement of Teaching (2003). Available online at <http:// www.carnegiefoundation.org/classification/ CIHE2000/defNotes/Definitions.htm>. 